\title{
Effects of diet, level of intake, sodium bicarbonate and monensin on urinary allantoin excretion in sheep
}

\author{
BY R. J. DEWHURST* AND A. J. F. WEBSTER \\ Department of Animal Husbandry, University of Bristol, Langford House, \\ Langford, Bristol BS18 $7 \mathrm{DU}$
}

(Received 20 February 1991-Accepted 19 June 1991)

\begin{abstract}
The present experiment was designed to study the effects of factors likely to alter microbial purine yield from the rumen on urinary excretion of allantoin-nitrogen (UAN). Sixteen mature Clun Forest-Welsh crossbred wethers were used in a $2 \times 2 \times 2 \times 2$ factorial design to investigate the effects of (1) level of intake, (2) wheat: nutritionally improved straw (NIS) ratio, (3) sodium bicarbonate inclusion and (4) monensin inclusion on diet digestibilities, fractional outflow rates of solids and liquids from the rumen and urinary allantoin excretion. Each treatment occurred in each of two experimental periods. The treatments were designed to influence microbial purine yield via changes in rumen outflow rate and microbial maintenance coefficient. Increasing the proportion of NIS and increasing feeding level decreased digestibility and increased the fractional outflow rate of solids. Increasing the level of intake increased the fractional outflow rate of liquids. Urinary allantoin excretion ( $/ \mathrm{kg}$ live weight ${ }^{075}$ per d) was significantly increased by an increased proportion of wheat in the diet and increased level of intake, and significantly reduced by $\mathrm{NaHCO}_{3}$. There was a significant interaction effect such that increasing level of intake did not increase UAN with the high-NIS diet, despite an increased fractional outflow of solids from the rumen, in contrast to the increase observed with the high-wheat diet. Taken together with other observations it is suggested that high sodium concentrations in the diet reduce the efficiency of microbial synthesis, probably by increasing the energy cost of maintaining osmolarity. Monensin had no overall effect on UAN but there were significant interactions between monensin and dietary $\mathrm{Na}$; the inhibitory effect of monensin on UAN was eliminated or reversed in the presence of added $\mathrm{NaHCO}_{3}$. This is consistent with theories that monensin increases the net influx of hydrogen ions into microbial cells and that this influx can be reduced by increased extracellular sodium ions.
\end{abstract}

Urinary allantoin: Rumen: Microbial maintenance coefficient: Sheep

Nucleic acids have been used widely to indicate the microbial content of digesta taken from the abomasum or duodenum (McAllan \& Smith, 1969). This approach was improved by the measurement of their component purine bases (Schelling et al. 1982), which are more robust and readily measured (Zinn \& Owens, 1986). To estimate the yield of microbial material from the rumen there was still a need for invasive techniques to assess the quantity of digesta flowing through the lower gut. Rys et al. (1975) proposed the use of urinary purine derivatives as indices of microbial yield from the rumen. Chen et al. (1990), using animals sustained by intragastric infusion, demonstrated a direct relationship between the supply of exogenous purine to the lower gut of sheep and their recovery as purine derivatives (hypoxanthine, xanthine, allantoin and uric acid) in urine. When purine derivative excretion exceeded $0.6 \mathrm{mmol} / \mathrm{kg}$ live weight $(\mathrm{W})^{0.75}$ per $\mathrm{d}$ there was no net

\footnotetext{
* Present address: Grassland and Ruminant Science Department, The Scottish Agricultural College,
} Auchincruive, Ayr KA6 5HW. 
endogenous contribution, i.e. endogenous losses were entirely replaced by utilization of exogenous purines. Above this level there was a linear relationship between the supply of exogenous purines and urinary excretion of purine derivatives with an apparent molar recovery of 0.84 . Below this level an increasingly large net endogenous contribution was evident, making the relationship non-linear, though nonetheless positive.

In the absence of other limitations, microbial energetic efficiency (E), the relationship between fermented energy supply and microbial yield from the rumen, is influenced by (1) the ratio microbial outflow (yield): total synthesis and (2) the maintenance energy costs of the population. Microbial maintenance energy costs include those of motility, lysis, uncoupling, inefficient phosphorylation, secretion and active transport (Harmeyer, 1986). Estimates of the microbial maintenance coefficient range from 0.75 to $3.50 \mathrm{mmol} \mathrm{ATP} / \mathrm{g}$ microbial dry matter (DM) per h (Harrison \& McAllan, 1980).

Dewhurst et al. (1987) demonstrated changes in urinary allantoin excretion, relative to energy supply, with changes in the fractional outflow rate of solids from the rumen $\left(K_{s}\right)$. This was interpreted as changes in E caused by increases in the ratio microbial yield : total synthesis. The present paper investigates further the effects on urinary allantoin excretion of factors designed to influence both fractional outflow rates from the rumen and the maintenance energy cost of the population. Level of intake, diet digestibility, proportion of nutritionally improved straw (NIS) and sodium bicarbonate treatments were imposed to manipulate fractional outflow rates from the rumen, whilst monensin was expected to influence the microbial maintenance coefficient.

\section{MATERIALS AND METHODS}

\section{Animals and their management}

Sixteen mature Clun Forest-Welsh crossbred wethers, weighing from 44 to $94 \mathrm{~kg}$ (mean 67 (SD 16) $\mathrm{kg}$ ) were used. The sheep were housed in digestibility crates for $14 \mathrm{~d}$ preliminary periods and for $10 \mathrm{~d}$ periods of total collection of faeces into canvas bags and urine over $100 \mathrm{ml} 2 \mathrm{M}$-sulphuric acid. Faeces and urine were removed daily and stored at $4^{\circ}$ before bulking and storage at $-20^{\circ}$ at the end of the collection period. Sheep were weighed and given the appropriate dose of anthelmintic at the start of each experimental period. Diets were fed in two equal portions at 09.00 and 16.00 hours and sheep had continual access to drinking water.

\section{Treatments and design}

Sixteen sheep were used in a $2 \times 2 \times 2 \times 2$ factorially-designed experiment to investigate four sources of variation in apparent digestibilities, fractional outflow rates and urinary allantoin excretion. The sixteen treatments were replicated in two experimental periods and consisted of all combinations of the following factors (a) 8.2 or $15.6 \mathrm{~g}$ feed DM $/ \mathrm{kg} \mathrm{W}$ per d, (b) wheat: NIS values of $0 \cdot 3: 0 \cdot 7$ and $0 \cdot 7: 0 \cdot 3$, (c) 0 or $50 \mathrm{~g} \mathrm{NaHCO}_{3} / \mathrm{kg}$ and (d) 0 or $22 \mathrm{mg}$ monensin $/ \mathrm{kg}$. During the 6 weeks between periods the sheep were grazed at pasture. The level of intake treatment was imposed according to the $\mathrm{W}$ of the sheep at the start of each experimental period. $\mathrm{NaHCO}_{3}$ was weighed separately and sprinkled onto each day's feed allowance. The other treatments were imposed by formulating four diets (Table 1) which were passed through a $6 \mathrm{~mm}$ screen and fed in a loose-meal form. The mineral-vitamin premix supplied (mg/kg air-dry feed) vitamin A 4.05, cholecalciferol $0 \cdot 068$, vitamin E 6.7, manganese 120 , zinc 220 , iron 20 , cobalt $0 \cdot 5$, iodine 5 , selenium $0 \cdot 2$, and molybdenum 1 . Since the level of intake, monensin and $\mathrm{NaHCO}_{3}$ treatments took account of sheep $\mathrm{W}$, the sheep were paired by W and randomly allocated to either the high-NIS or high-wheat diets; within these groups sheep were randomly allocated to the eight treatments. 
Table 1. Diet formulations $(\mathrm{g} / \mathrm{kg}$ air dry feed)

\begin{tabular}{lrrrr}
\hline \hline Diet no... & \multicolumn{1}{c}{ 1 } & \multicolumn{1}{c}{3} & 3 & 4 \\
\hline Wheat & 283 & 663 & 283 & 663 \\
Nutritionally improved straw* & 659 & 284 & 659 & 284 \\
Dicalcium phosphate & 30 & 30 & 30 & 30 \\
Urea & 20 & 15 & 20 & 15 \\
Mineral-vitamin premix & 8 & 8 & 8 & 8 \\
Monensin premix $(100 \mathrm{~g} / \mathrm{kg})$ & 0 & 0 & $0 \cdot 22$ & $0 \cdot 22$ \\
\hline
\end{tabular}

* 32 Viton-NIS; Unitrition International Ltd, Basingstoke, Hants.

\section{Fractional outflow rates from the rumen}

Fractional outflow rates from the rumen for the solid- and liquid-phases of rumen digesta ( $K_{s}$ and $K_{l}$ respectively) were determined using chromium-mordanted straw neutraldetergent fibre (NDF) and CoEDTA respectively (Uden et al. 1980). Sheep were given a pulse oral dose of $12 \mathrm{~g}$ labelled fibre and $8 \mathrm{~g}$ CoEDTA in approximately $250 \mathrm{ml}$ water immediately before their morning feed. A daily subsample of the total collection of faeces was taken before the morning feeding on each of the following $10 \mathrm{~d}$ and dried at $100^{\circ}$ in preparation for marker analysis.

\section{Analytical methods}

Samples were analysed, as appropriate, for proximate constituents (Association of Official Agricultural Chemists, 1965), NDF (Robertson \& Van Soest, 1977), acid-detergent fibre and acid-detergent lignin (Van Soest $\&$ Wine, 1967). Cr and Co were determined by atomic absorption spectrophotometry and $\mathrm{Na}$ by flame photometry, both following a wetdigestion procedure (Milner \& Whiteside, 1981). Acid-detergent-insoluble nitrogen (ADIN) was determined by performing a Kjeldahl $\mathrm{N}$ determination on an acid-detergent fibre residue. Allantoin in urine was determined using an autoanalyser method based on the colorimetric reaction of Borchers (1977). The autoanalyser was found to be extremely advantageous for this method since the manual method is highly sensitive to the timing of manipulations. Calibration curves were non-linear but could be linearized $(r>0.99)$ by performing a double-reciprocal plot. The addition of allantoin to a sample of urine with a low $(0 \cdot 184(\mathrm{SE} 0 \cdot 005) \mathrm{g} / \mathrm{l})$ allantoin content showed recoveries of 0.98-1.04. Earlier work demonstrated the stability of allantoin in urine preserved with the level of sulphuric acid used in the present trial and kept at $4^{\circ}$ or $-20^{\circ}$ (Dewhurst, 1989).

\section{Statistics}

Results were analysed using the residual maximum likelihood (REML) directive of GENSTAT 5 (Lawes Agricultural Trust, 1987). The model looked at period effects and the main and two-factor interaction effects of level of intake, diet, $\mathrm{NaHCO}_{3}$ and monensin. Sheep were treated as a random variable. The most conservative estimates of residual degrees of freedom were used in arriving at levels of significance. Linear regression was undertaken using the MINITAB statistical package (Minitab Inc., 1980). Fitting of fractional outflow rates from the rumen involved selection, by eye, of points on the log descending phase of the marker excretion curve, followed by linear regression $v$, time. The slope of this line was taken to be the fractional outflow rate from the rumen. The number of daily samples included in these regressions varied with fractional outflow rate, though usually samples from days 2 to 6 were included. 
Table 2. Chemical analysis of the wheat, nutritionally improved straw (NIS) and diets used in the experiment $(\mathrm{g} / \mathrm{kg}$ dry matter)

\begin{tabular}{lccrrrrr}
\hline \multicolumn{8}{c}{ Diets } \\
\hline & Wheat & NIS & 1 & 2 & 3 & 4 \\
\hline Ash & 32 & 115 & 100 & 68 & 99 & 80 \\
CP & 134 & 44 & 139 & 144 & 119 & 146 \\
EE & 10 & 14 & 12 & 12 & 12 & 10 \\
CF & 27 & 371 & 244 & 134 & 248 & 113 \\
NFE & 797 & 460 & 505 & 642 & 522 & 651 \\
NDF & 108 & 623 & 444 & 272 & 456 & 273 \\
ADF & 31 & 480 & 315 & 174 & 323 & 134 \\
ADL & 18 & 74 & 54 & 37 & 51 & 33 \\
ADIN & $0 \cdot 6$ & $2 \cdot 5$ & $1 \cdot 9$ & $1 \cdot 4$ & $2 \cdot 0$ & $1 \cdot 2$ \\
Sodium & & & 20 & 13 & 23 & 10 \\
\hline
\end{tabular}

$\mathrm{CP}$, crude protein (nitrogen $\times 6.25$ ); EE, diethyl ether extract; $\mathrm{CF}$, crude fibre; NFE, $\mathrm{N}$-free extractives; NDF, neutral-detergent fibre; ADF, acid-detergent fibre; ADL, acid-detergent lignin; ADIN, acid-detergent-insoluble N.

\section{RESULTS}

The chemical analyses of the diets used are given in Table 2. The diets were fed at DM contents ranging from 869 to $898 \mathrm{~g} / \mathrm{kg}$. A few day's urine collections were lost owing to carboys running over or being knocked over and results were corrected for this. In the second period two sheep refused to eat a considerable portion of their allocated feed; their values were treated as missing values in subsequent analyses since level of feeding was a major source of variation being tested. Other feed refusals were negligible. Urine volumes tended to be very large (mean $3.3(\mathrm{SD} 1.5) 1 / \mathrm{d}$, range $1 \cdot 3-7 \cdot 1$ including approximately 0.51 washings/d), probably owing to a combination of warm weather and high intakes of $\mathrm{Na}$. Urinary allantoin-N (UAN) excretion ranged from 120 to 1140 (mean 466 (SD 242)) $\mathrm{mg} /$ animal per $\mathrm{d}$. This represented a range of $4.7-42.0$ (mean 19.8 (SD 9.0)) $\mathrm{mg} / \mathrm{kg}$ $\mathrm{W}^{0.75}$ per $\mathrm{d}$ and 0.27 to 1.37 (mean 0.79 (SD 0.24)) $\mathrm{g} / \mathrm{kg}$ digestible organic matter (DOM).

Table 3 summarizes the main effects of diet, level of intake and the inclusion of $\mathrm{NaHCO}_{3}$ and monensin on digestibility of DM, NDF and neutral-detergent solubles (NDS), $K_{s}$ and $K_{l}$, and daily UAN excretion.

Increasing the ratio wheat: NIS from $0 \cdot 3: 0 \cdot 7$ to $0 \cdot 7: 0 \cdot 3$ had the expected effects on digestibility, significantly increasing the digestibility of DM and NDS but decreasing the digestibility of NDF. The 0.7 wheat: 0.3 NIS diet also produced a significantly greater excretion of UAN whether expressed as $\mathrm{mg} / \mathrm{kg} \mathrm{W}^{0.75}$ per $\mathrm{d}$ or $\mathrm{g} / \mathrm{kg}$ DOM.

Increasing the level of intake significantly reduced the apparent digestibility of DM and NDF, but not NDS which is more rapidly fermented, and increased both $K_{s}$ and $K_{l}$. UAN increased significantly when expressed as $\mathrm{mg} / \mathrm{kg} \mathrm{W}^{0.75}$ per $\mathrm{d}$, but remained unchanged when expressed as $\mathrm{g} / \mathrm{kg}$ DOM. Table 4 shows the significant interaction between diet type and level of intake on UAN. UAN was increased with increasing level of intake when feeding with the high-wheat diet, whilst there was no significant level of intake effect with the highNIS diet.

Addition of $\mathrm{NaHCO}_{3}$ significantly increased the digestibility of DM, NDF and NDS; $K_{s}$ and $K_{l}$ were unaffected but UAN was significantly reduced. Effects of monensin on all variables were small and, considered in isolation, reveal no consistent pattern. There were, however, significant interactions between monensin and $\mathrm{NaHCO}_{3}$ (Table 4). Monensin 
Table 3. Effects of diet $\dagger(d)$, level of intake (1), $\mathrm{NaHCO}_{3}(b)$ and monensin $(m)$ on the apparent digestibility of dry matter (DMD), neutral-detergent fibre (NDFD) and solubles $(N D S D)$, fractional outflow rates from the rumen of solids $\left(\mathrm{K}_{\mathrm{s}}\right)$ and liquid $\left(\mathrm{K}_{1}\right)$ and urinary allantoin $N$ excretion $(U A N) \ddagger$

(Values are means with their standard error of difference for each pair of values given in parentheses)

\begin{tabular}{|c|c|c|c|c|c|c|c|c|}
\hline & Wheat:NIS & $\begin{array}{c}\text { Intake } \\
\text { level }\end{array}$ & $\begin{array}{c}\mathrm{NaHCO}_{3} \\
(\mathrm{~g} / \mathrm{kg})\end{array}$ & $\begin{array}{l}\text { Monensin } \\
(\mathrm{mg} / \mathrm{kg})\end{array}$ & \multicolumn{4}{|c|}{$\begin{array}{l}\text { Statistical } \\
\text { significance } \\
\text { of effects }\end{array}$} \\
\hline & $0 \cdot 3: 0 \cdot 7 \quad 0 \cdot 7: 0 \cdot 3$ & Low High & 50 & 22 & d & 1 & b & $\mathrm{m}$ \\
\hline DMD & $\begin{array}{c}0.67 \quad 0.74 \\
(0-005)\end{array}$ & $\begin{array}{c}0.73 \quad 0.68 \\
(0.005)\end{array}$ & $\begin{array}{c}0.69 \quad 0.71 \\
(0.005)\end{array}$ & $\begin{array}{c}0.71 \quad 0.70 \\
(0.004)\end{array}$ & $* * *$ & $* * *$ & * & NS \\
\hline NDFD & $\begin{array}{c}0.63 \quad 0.57 \\
(0.019)\end{array}$ & $\begin{array}{c}0.65 \quad 0.56 \\
(0.019)\end{array}$ & $\begin{array}{c}0.57 \quad 0.63 \\
(0.019)\end{array}$ & $\begin{array}{c}0.60 \quad 0.61 \\
(0.018)\end{array}$ & $*$ & $* *$ & $*$ & NS \\
\hline NDSD & $\begin{array}{c}0.69 \quad 0.81 \\
(0.005)\end{array}$ & $\begin{array}{c}0.75 \quad 0.74 \\
(0.005)\end{array}$ & $\begin{array}{c}0.74 \quad 0.76 \\
(0.006)\end{array}$ & $\begin{array}{c}0.76 \quad 0.74 \\
(0.004)\end{array}$ & $* * *$ & NS & $*$ & $*$ \\
\hline$K_{s}(\% / \mathrm{h})$ & ${ }^{3.27}(0.392)^{1.79}$ & $\begin{array}{c}1.92 \quad 3 \cdot 14 \\
(0 \cdot 422)\end{array}$ & $\begin{array}{c}2 \cdot 15 \quad 2 \cdot 91 \\
(0 \cdot 422)\end{array}$ & $\begin{array}{c}2.95 \quad 2.11 \\
(0.372)\end{array}$ & $*$ & $*$ & NS & NS \\
\hline$K_{l}(\% / \mathrm{h})$ & ${ }^{3.90}(0.521)^{3.54}$ & $\begin{array}{c}2 \cdot 77 \quad 4 \cdot 66 \\
(0 \cdot 521)\end{array}$ & $\begin{array}{c}3.62 \quad 3.82 \\
(0.521)\end{array}$ & $\begin{array}{c}4.32 \quad 3.12 \\
(0.521)\end{array}$ & NS & ** & NS & NS \\
\hline UAN : $\mathrm{mg} / \mathrm{kg} \mathrm{W}^{0.75}$ per d & $\left.{ }_{(1.295)}^{15.6}\right)^{23.7}$ & $\begin{array}{c}14 \cdot 4 \quad 24 \cdot 9 \\
(1 \cdot 310)\end{array}$ & $\begin{array}{c}22.4 \quad 16.9 \\
(1.355)\end{array}$ & $\begin{array}{c}20-6 \quad 18-6 \\
(1 \cdot 216)\end{array}$ & $* * *$ & $* * *$ & $* *$ & NS \\
\hline $\mathrm{g} / \mathrm{kg} \mathrm{DOM}$ & $\begin{array}{c}0.68 \quad 0.87 \\
(0.059)\end{array}$ & $\begin{array}{c}0.77 \quad 0.77 \\
(0.060)\end{array}$ & $\begin{array}{cc}0.89 & 0.66 \\
(0.062)\end{array}$ & $\begin{array}{c}0.79 \quad 0.76 \\
(0.055)\end{array}$ & $*$ & NS & $* *$ & NS \\
\hline
\end{tabular}

NIS, nutritionally improved straw; NS, not significant; $W$, live weight; DOM, digestible organic matter.

* $P<0.05,{ }^{* *} P<0.01,{ }^{* * *} P<0.001$.

+ For details, see Tables 1 and 2 .

+ For details of procedures, see pp. $346-347$

Table 4. Interaction effects on the apparent digestibility of neutral-detergent fibre (NDFD) and urinary allantoin $N$ excretion $(U A N ; m g / k g$ digestible organic matter $(D O M)$ and $m g / k g$ $W^{n-75}$ per $\left.d\right)^{*}$

\begin{tabular}{|c|c|c|c|c|c|c|}
\hline \multirow{2}{*}{$\begin{array}{l}\text { (1) Diet } \times \text { level of intake interaction } \\
\text { Wheat : NIS ... } \\
\text { Level of intake... }\end{array}$} & \multicolumn{2}{|c|}{$0 \cdot 3: 0 \cdot 7$} & \multicolumn{2}{|c|}{$0 \cdot 7: 0 \cdot 3$} & \multirow[b]{2}{*}{ SED } & \multirow{2}{*}{$\begin{array}{c}\text { Statistical } \\
\text { significance } \\
\text { of interaction } \\
P \\
\end{array}$} \\
\hline & Low & High & Low & High & & \\
\hline $\begin{array}{l}\text { UAN : } \mathrm{mg} / \mathrm{kg} \mathrm{W}^{0 \cdot 75} \text { per d } \\
\text { UAN g/kg DOM }\end{array}$ & $\begin{array}{l}13 \cdot 3^{\mathrm{a}} \\
0 \cdot 76^{\mathrm{a}, \mathrm{b}}\end{array}$ & $\begin{array}{l}17 \cdot 8^{a} \\
0 \cdot 60^{\mathrm{a}}\end{array}$ & $\begin{array}{l}15 \cdot 4^{\mathrm{a}} \\
0 \cdot 78^{\mathrm{a}, \mathrm{b}}\end{array}$ & $\begin{array}{l}32 \cdot 0^{b} \\
0 \cdot 95^{b}\end{array}$ & $\begin{array}{l}2 \cdot 16 \\
0.099\end{array}$ & $\begin{array}{l}<0.001 \\
<0.01\end{array}$ \\
\hline $\begin{array}{l}\text { (2) Monensin } \times \text { sodium interaction } \\
\text { Sodium bicarbonate }(\mathrm{g} / \mathrm{kg}) \ldots \\
\text { Monensin }(\mathrm{mg} / \mathrm{kg}) \ldots\end{array}$ & \multicolumn{2}{|c|}{0} & \multicolumn{2}{|c|}{50} & SED & $\begin{array}{c}\text { Statistical } \\
\text { significance } \\
\text { of interaction } \\
P\end{array}$ \\
\hline $\begin{array}{l}\text { NDFD } \\
\text { UAN : } \mathrm{mg} / \mathrm{kg} \mathrm{W}^{0.35} \text { per d } \\
\quad \mathrm{g} / \mathrm{kg} \mathrm{DOM}^{-}\end{array}$ & $\begin{array}{l}0 \cdot 55^{\mathrm{a}} \\
25 \cdot 1^{\mathrm{a}} \\
0 \cdot 97^{\mathrm{a}}\end{array}$ & $\begin{array}{l}0 \cdot 60^{\mathrm{a}, \mathrm{b}} \\
19 \cdot 6^{\mathrm{b}} \\
0 \cdot 82^{\mathrm{a}, \mathrm{b}}\end{array}$ & $\begin{array}{l}0 \cdot 65^{\mathrm{b}} \\
16 \cdot 2^{\mathrm{b}} \\
0 \cdot 61^{\mathrm{b}}\end{array}$ & $\begin{array}{l}0 \cdot 61^{b} \\
17 \cdot 6^{b} \\
0 \cdot 70^{h}\end{array}$ & $\begin{array}{l}0 \cdot 027 \\
1.89 \\
0 \cdot 086\end{array}$ & $\begin{array}{l}<0.05 \\
<0.05 \\
<0.05\end{array}$ \\
\hline
\end{tabular}

$a . b$ Values in the same row with different superscript letters were significantly different at the level indicated.

NIS, nutritionally improved straw; SED, standard error of difference.

* For details of procedures, see pp. $346-347$ 
increased the digestibility of NDF and decreased UAN $\left(\mathrm{g} / \mathrm{kg}\right.$ DOM and $\mathrm{mg} / \mathrm{kg} \mathrm{W}^{0, \tau 5}$ per d) in the absence of $\mathrm{NaHCO}_{3}$, whilst these effects were negligible or reversed in the presence of $\mathrm{NaHCO}_{3}$.

\section{DISCUSSION \\ Apparent digestibilities}

Treatment effects on apparent digestibilities were broadly as expected. Wheat NDF (bran) was significantly $(P<0.05)$ less digestible than NDF from NIS despite the significantly $(P<0.05)$ lower $K_{s}$ acting on the high-wheat diet $(0.018 v .0 .033 / \mathrm{h})$. There was no overall effect of monensin on apparent digestibility. There was, however, a significant interaction effect with $\mathrm{NaHCO}_{3}$ on the apparent digestibility of NDF. In the absence of $\mathrm{NaHCO}_{3}$ monensin increased the apparent digestibility of NDF whilst the effect was reversed in the presence of $\mathrm{NaHCO}_{3}$. The effect of monensin on fibre digestion (in the absence of $\mathrm{NaHCO}_{3}$ ) is the opposite of that noted in the review of Demeyer et al. (1986). It is, however, consistent with the findings of Allen \& Harrison (1979) and may be explained by the same mechanism of increased rumen retention times (a non-significant trend in the current work).

\section{Fractional outflow rates from the rumen}

Significant increases in $K_{s}$ were associated with increases in the level of intake and reductions in digestibility at a given level of intake. This is in agreement with the regression analysis of literature values undertaken by Evans $(1981 \mathrm{~b})$. Increasing level of intake increased $K_{l}$, in agreement with Evans $(1981 a)$, though in the present experiment there was no evidence of a depression in $K_{l}$ with increasing energy density of the diet. $K_{l}$ was on average 0.5 greater than $K_{s}(0.036$ v. $0.024 / \mathrm{h})$. The reduction in $K_{l}$ with monensin was consistent with the majority of experiments reviewed by Bergen \& Bates (1984), though the absence of an effect of $\mathrm{NaHCO}_{3}$ was more surprising, this being an initial objective of this treatment.

\section{Urinary allantoin excretion}

For several dietary treatments the level of urinary allantoin excretion was below $0.6 \mathrm{mmol} / \mathrm{kg} \mathrm{W}^{0 \cdot 75}$ per $\mathrm{d}$. In these circumstances the findings of Chen et al. (1990) would predict a significant net endogenous contribution to allantoin excretion. Thus, the reduction in microbial yield caused by some of the treatments is likely to be greater than is apparent from considering UAN.

UAN increased with increasing proportion of wheat in the diet and with increasing level of intake, and was reduced by the inclusion of $\mathrm{NaHCO}_{3}$ in the diet. The effect of level of intake was proportional to the increase in DOM intake, so that increasing level of intake had no effect on urinary allantoin excretion $/ \mathrm{kg}$ DOM. Since it is likely (Chen et al. 1990) that there was a net endogenous allantoin excretion at the low level of intake this observation is not inconsistent with an increasing $\mathrm{E}$ with increasing level of intake. There was no significant relationship between urinary allantoin excretion (expressed per $\mathrm{kg}$ DOM) and fractional outflow rates from the rumen, despite $K_{s}$ ranging from 0.76 to $6.77 / \mathrm{h}$ and $K$, from 1.66 to $6.79 / \mathrm{h}$. This may have resulted from a net endogenous allantoin contribution at low outflow rates or the greater effect of other sources of variation in microbial yields. $\mathrm{NaHCO}_{3}$ did not increase fractional outflow rates from the rumen as had been expected so that effects on UAN must have been mediated by some other means. The effects of $\mathrm{Na}$ supplementation in the present experiment are confounded somewhat by the high concentration of $\mathrm{Na}$ in the NIS used. It is, however, possible to examine the effect of $\mathrm{Na}$ in both NIS and $\mathrm{NaHCO}_{3}$ by comparing effects of diets with and without $\mathrm{NaHCO}_{3}$ supplementation. Table 5 presents results from the present study and an earlier experiment 
Table 5. Comparison of the effects of changing from 0.3:0.7 to 0.7:0.3 nutritionally improved straw $(N I S)$ : wheat, with different sodium concentrations in the straw samples*

(Values are means and standard deviations for observations based on the results of the present experiment and that presented by Dewhurst et al. (1987))

\begin{tabular}{|c|c|c|c|c|c|c|c|c|c|c|c|c|c|}
\hline \multirow{3}{*}{$\begin{array}{l}\text { Na content of } \\
\text { NIS }(g / k g ~ D M)\end{array}$} & \multirow{3}{*}{$\begin{array}{l}\mathrm{NaHCO}_{3} \\
(\mathrm{~g} / \mathrm{kg})\end{array}$} & \multicolumn{6}{|c|}{$\begin{array}{l}\text { Urinary allantoin-N } \\
(\mathrm{g} / \mathrm{kg} \mathrm{DOM})\end{array}$} & \multicolumn{6}{|c|}{$K_{s}(\% / \mathrm{h})$} \\
\hline & & \multicolumn{3}{|c|}{$0 \cdot 3: 0 \cdot 7$} & \multicolumn{3}{|c|}{$0 \cdot 7: 0 \cdot 3$} & \multicolumn{3}{|c|}{$0 \cdot 3: 0 \cdot 7$} & \multicolumn{3}{|c|}{$0 \cdot 7: 0 \cdot 3$} \\
\hline & & $n$ & Mean & SD & $n$ & Mean & SD & $n$ & Mean & SD & $n$ & Mean & SD \\
\hline $11 \cdot 0$ & 0 & 3 & 1.04 & $0 \cdot 48$ & 3 & 1.79 & 0.08 & 3 & $2 \cdot 25$ & 0.69 & 3 & $2 \cdot 83$ & 0.32 \\
\hline $23 \cdot 4$ & 0 & 3 & $1 \cdot 41$ & $0 \cdot 34$ & 3 & 1.46 & 0.32 & 3 & 1.54 & 0.51 & 3 & $2 \cdot 28$ & 0.42 \\
\hline $29 \cdot 5$ & 0 & 4 & 0.71 & $0 \cdot 15$ & 4 & 0.65 & 0.29 & 4 & 1.99 & 0.96 & 4 & 2.51 & 1.67 \\
\hline $29 \cdot 5$ & 50 & 4 & 1.03 & 0.26 & 3 & 0.78 & 0.15 & 4 & $2 \cdot 81$ & 0.27 & 3 & $4 \cdot 01$ & 0.92 \\
\hline
\end{tabular}

DM. dry matter; DOM, digestible organic matter; $K_{s}$, fractional outflow rate from the rumen of solids.

* For details of procedure, see pp. 346 and 351.

(Dewhurst et al. 1987) which used identical procedures to those used in the present experiment and a single level of feed intake, irrespective of $\mathrm{W}$, which averaged $12.6 \mathrm{~g}$ feed $\mathrm{DM} / \mathrm{kg} \mathrm{W}$ per $\mathrm{d}$. This comparison shows that increasing the NIS proportion of NIS-wheat diets from 0.3 to 0.7 increased UAN $/ \mathrm{kg}$ DOM when $\mathrm{Na}$ concentration in NIS was 11.0 $\mathrm{g} / \mathrm{kg} \mathrm{DM}$, presumably via the increase in $K_{s}$. As Na concentration in NIS increased, this increase first disappeared and then reversed despite an increase in $K_{s}$ in all cases. This strongly suggests that increasing $\mathrm{Na}$ supply at high levels reduces $\mathrm{E}$; increased energy costs of osmoregulation are a likely mechanism (Mackie \& Therion, 1984). This effect also explains the level of intake $\times$ diet interaction effect on UAN (Table 4), with the effect of increasing level of intake suppressed by the effect of a very large supply of $\mathrm{Na}$ with the highNIS diet.

Although monensin had no overall effect on urinary allantoin excretion, there was a significant interaction with $\mathrm{Na}$ (Table 4). The reduction in UAN noted when monensin was added in the absence of $\mathrm{NaHCO}_{3}$ was reversed in the presence of $\mathrm{Na}$. Both recent models of monensin action (Bergen \& Bates, 1984; Russell, 1987) envisage monensin increasing the net influx of hydrogen ions into microbial cells, i.e. reducing the transmembrane proton motive force, and thereby reducing microbial yield and efficiency. The interaction between monensin and $\mathrm{Na}$ noted here can be explained by both models; in the former model increased extracellular sodium ions reduces the influx of $\mathrm{H}^{+}$whilst in the latter it increases the efflux of $\mathrm{H}^{+}$without expenditure of ATP.

An interaction between $\mathrm{Na}$ and monensin in their effects on a number of measures of the growth and efficiency of both host animals and rumen microbes in vitro has been demonstrated frequently (Perski et al. 1982; Rogers \& Davis, 1982; Rumpler et al. 1986; Schwingel et al. 1989). The effect of urinary allantoin excretion (E) noted in the present experiment is consistent with the in vitro results of Mackie \& Therion (1984) in which the negative effect of monensin on bacterial yield (per unit glucose used) was reduced by increasing extracellular $\mathrm{Na}$.

Reduced $\mathrm{E}$ on the addition of monensin (without high levels of $\mathrm{Na}$ ) have been observed by Poos et al. (1979) and Isichei \& Bergen (1980) in vivo and by Van Nevel \& Demeyer (1977) using a constant outflow rate in vitro system. Hoeller et al. (1985) used both ${ }^{15} \mathrm{~N}$ and thiamin net synthesis to demonstrate reduced microbial yields in dairy cows given monensin at $33 \mathrm{mg} / \mathrm{kg}$. E was reduced from 1.47 to $1.12 \mathrm{~g}$ microbial $\mathrm{N}(\mathrm{MN}) / \mathrm{MJ}$ 
metabolizable energy (ME) $\left({ }^{15} \mathrm{~N}\right.$ values). For wether sheep, Allen \& Harrison (1979) estimated a 0.14 decline in $E$ with inclusion of monensin. Laurent \& Vignon (1979) and Laurent et al. (1980) demonstrated a reduced urinary allantoin excretion when monensin was included in diets, though the effect may have partly resulted from reduced levels of intake.

The demonstration of this interaction effect in vivo is an illustration of the strength of the urinary allantoin excretion technique in permitting the identification of the effects of a number of the many interacting factors that influence microbial yield from the rumen. It is likely that a number of other important factors contribute to the large variation in $E$ noted in the literature (Agricultural Research Council, 1984). Assuming that energy (ATP) is the limiting factor for microbial yield, these will operate by one of the two routes demonstrated in the present paper and the paper of Dewhurst et al. (1987), these being fractional outflow rates from the rumen and the microbial maintenance coefficient.

The Agricultural Research Council (1984) preferred value of $1.34 \mathrm{~g} \mathrm{MN} / \mathrm{MJ}$ ME is clearly only applicable to ruminants fed in a similar way to the majority of animals used to derive this mean value, i.e. standard diets given at close to the maintenance level of intake. The model of Webster (1987) attempted to take account of plane of nutrition and diet digestibility effects on $\mathrm{E}$, but ignored factors influencing the microbial maintenance coefficient. These experiments reveal that the non-invasive method for estimation of microbial protein yield from urinary purine derivative excretion offers a powerful approach to the analysis of the complex factors affecting outflow and maintenance energy costs of the microbial population in the rumen which can, after further study, be incorporated into improved models.

The technical assistance of Messrs M. Kitcherside, M. Badman and J. Sampson is gratefully acknowledged. This work was supported by The Science and Engineering Research Council and Dalgety Agriculture Ltd.

\section{REFERENCES}

Agricultural Research Council (1984). The Nutrien Requiremenis of Ruminant Livestock, Suppl. 1. Farnham Royal: Commonwealth Agricultural Bureaux.

Allen, J. D. \& Harrison, D. G. (1979). The effect of dictary monensin upon digestion in the stomachs of sheep. Proceedings of the Nutrition Society 38,32A.

Association of Official Agricultural Chemists (1965). Methods of Analysis, 10th ed. Washington, DC: Association of Official Agricultural Chemists.

Bergen, W. G.\& Bates, D. B. (1984). Ionophores: their effect on production efficiency and mode of action. Journal of Animal Science $\mathbf{5 8}, 1465-1483$.

Borchers, R. (1977). Allantoin determination. Analytical Biochemistry 79, 612-613.

Chen, X. B., Hovell, F. D. DeB., Ørskov, E. R. \& Brown, D. S. (1990). Excretion of purine derivatives by ruminants: effect of exogenous nucleic acid supply on purine derivative excretion by sheep. British Joumal of Nutrition 63, 131-142.

Demeyer, D., Van Nevel, C. J., Teller, E. \& Godeau, J. M. (1986). Manipulation of rumen digestion in relation to the level of production in ruminants. Archives of Animal Nutrition 36, 132-143.

Dewhurst, R. J. (1989). Studies on energy and nitrogen metabolism in the rumen: investigation of less invasive techniques for these studies. PhD Thesis, University of Bristol.

Dewhurst, R. J., Waters, C. J. \& Webster, A. J. F. (1987). Use of urinary allantoin excretion to assess the energetic efficiency of microbial protein yield in sheep. Animal Production 44, 475A.

Evans, E. $(1981 a)$. An evaluation of the relationship between dietary parameters and rumen liquid turnover rate. Canadian Journal of Animal Science 61, 91-96.

Evans, E. (1981 b). An evaluation of the relationship between dietary parameters and rumen solid turnover rate. Canadian Journal of Animal Science 61, 97-103.

Harmeyer, J. (1986). Energy expenditures of rumen microbes for maintenance. Archives of Animal Nutrition 36, $143-148$. 
Harrison, D. G. \& McAllan, A. B. (1980). Factors affecting microbial growth yields in the rumen. In Digestive Physiology and Metabolism in Ruminants, pp. 205-226 [Y. Ruckebush and P. Thivend, editors]. Lancaster: MTP Press.

Hoeller, H., Breves, G., Lebzien, P. \& Rohr, K. (1985). Effects of monensin on net synthesis of thiamin and microbial protein in the rumen of cows. Proceedings of the Nutrition Society 44, $146 \mathrm{~A}$.

Isichei, C. O. \& Bergen, W. G. (1980). The effect of monensin on the composition of abomasal nitrogen flow in steers fed grain and silage rations. Journal of Animal Science 51, Suppl. 371 A-372A.

Laurent, F. \& Vignon, B. (1979). Variations de l'excrétion urinaire d'azote total, d'urée et d'allantoïne chez le mouton et chez le bouc (Variation in the urinary excretion of total nitrogen, urea and allantoin by wether sheep and male goats), Bulletin ENSAIA, Nancy 21, 115-124.

Laurent, F., Blanchart, G. \& Vignon, B. (1980). Effet de l'addition de monensin sur la valeur alimentaire de la ration et sur l'utilization d'azote par les moutons et par les boucs (Effect of monensin on nutritive value and nitrogen utilization in sheep and goats). Bulletin ENSAIA, Nancy 22, 43-49.

Lawes Agricultural Trust (1987). Genstat 5. Harpenden: Rothamsted Experimental Station.

McAllan, A. B. \& Smith, R. H. (1969). Nucleic acid metabolism in the ruminant. Determination of nucleic acids in digesta. British Journal of Nutrition 23, 671-682.

Mackie, R. I. \& Therion, J. J. (1984). Influence of mineral interactions on the growth efficiency of rumen bacteria. In Herbivore Nutrition, pp. 455477 [F. M. C. Gilchrist and R. I. Mackie, editors]. Craighall, South Africa: Science Press

Milner, B. A.\& Whiteside, P. J. (1981). Introduction to Atomic Absorption Spectrophotometry, 2nd ed. Cambridge: Pye Unicam Ltd.

Minitab Inc. (1980). Minitab Data Analysis Software. Pennsylvania: Pennsylvania State College.

Perski, H. J., Schonheit, P. \& Thauer, R. K. (1982). Sodium dependence of methane formation in methanogenjc bacteria. FEBS Letters 143, 323-326.

Poos, M. I., Hanson, T. L. \& Klopfenstein, T. J. (1979). Monensin effects on diet digestibility, ruminal protein bypass and microbial protein synthesis. Journal of Animal Science 48, 1516-1524.

Robertson, J. B. \& Van Soest, P. J. (1977). Dietary fiber estimation in concentrate feedstuffs. Journal of Animal Science 45, Suppl. 1, 254A.

Rogers, J. A.\& Davis, C. L. (1982). Rumen volatile fatty acid production and nutrient utilization in steers fed a diet supplemented with sodium bicarbonate and monensin. Journal of Dairy Science 65, 944-952.

Rumpler, W. V., Johnson, D. E. \& Bates, D. B. (1986). The effect of high dietary cation concentration on methanogenesis by steers fed diets with and without ionophores. Journal of Animal Science 62, 1737--1741.

Russell, J. B. (1987). A proposed mechanism of monensin action in inhibiting ruminal bacterial growth : effects on ion flux and proton motive force. Journal of Animal Science 64, 1519-1525.

Rys, R., Antoniewicz, A. \& Maciejewicz, J. (1975). Allantoin in urine as an index of microbial protein in the rumen. In Tracer Studies on Non-protein-nitrogen for Ruminants (2), pp. 95-98. Vienna: International Atomic Energy Authority.

Schelling, G. T., Koenig, S. E. \& Jackson, T. J. (1982). Nucleic acids and purine or pyrimidine bases as markers for protein synthesis in the rumen. In Protein Requirement for Cattle: Symposium, pp. 1-9 [F. N. Owens, editor] Stillwater: Oklahoma State University.

Schwingel, W. R., Bates, D. B., Denham, S. C. \& Beede, D. K. (1989). Effect of potassium and sodium on in virro ruminal fermentations containing lasalocid or monensin. Nutrition Reports International 39, 735-747.

Uden, P., Colucci, P. E. \& Van Soest, P. J. (1980). Investigation of chromium, cerium and cobalt as markers in digesta. Rate of passage studies. Journal of the Science of Fond and Agriculture 31, 625-632.

Van Nevel, C. J. \& Demeyer, D. I. (1977). Effect of monensin on rumen metabolism in vitro. Applied and Environmental Microbiology 34, 25!-257.

Van Soest, P. J. \& Wine, R. H. (1967). Use of detergents in the analysis of fibrous feeds (4) Determination of plant cell-wall constituents. Journal of the Association of Official Agricultural Chemists 50, 50-55.

Webster, A. J. F. (1987). Metabolizable protein - the U.K. approach. In Feed Evaluation and Protein Requirements Systems for Ruminants, pp. 47-53 [R. Jarrige and G. Alderman, editors]. Luxemburg: Office of the Official Publications of The European Communities.

Zinn, R. A. \& Owens, F. N. (1986). A rapid procedure for purine measurement and its use for estimating net ruminal protein synthesis. Canadian Journal of Animal Science 66, 157-166. 